\title{
Miks mõnikord kaob tuju eesti keelt õppida? \\ Demotivatsioon üheksanda klassi eesti keele kui teise keele tundides
}

MARE KITSNIK ${ }^{1}$, MONIKA SOOALU

Tartu Ülikool ${ }^{1}$

Ülevaade. Õpilasele mõjuvad teise keele tunnis alati mitmesugused seotud tegurid. Kui need on positiivse mõjuga, siis motiveerivad nad õpilast õppima. Kui mõju on aga vastupidine, siis mõjuvad nad õpilasele demotiveerivalt ehk kahandavad tema õppimissoovi. Artiklis vaadeldakse üheksanda klassi eesti keele kui teise keele tundides õpilastele mõjuda võivaid demotiveerivaid tegureid. Artikli aluseks olevas uuringus on viidud läbi suulised individuaalsed poolstruktureeritud intervjuud 20 üheksanda klassi õpilasega neljast Tallinna vene õppekeelega koolist ja nende õpilaste eesti keele õpetajatega. Intervjuude analüüsil on selgunud 16 peamist demotiveerivat tegurit, mis jagunevad kolme suurde rühma: õpetajaga seotud, õppeteemade ja -tegevustega seotud ning õpperühmaga seotud tegurid. Õpetajatel oleks kasulik õpilasi demotiveerivaid tegureid paremini tunda, mis võimaldaks neil teha õppetöös vajalikke muudatusi.

Võtmesõnad: õpimotivatsioon; demotivatsioon; õpetaja; õppetegevused; õpperühm; eesti keel teise keelena 


\section{Sissejuhatus}

Eesti keelest erineva emakeelega õpilased õpivad Eestis koolis käies eesti keelt teise keelena (ingl second language). Põhikooli lõpuks on õpilased läbinud suure hulga eesti keele tunde (umbes 1000), kuid eesti keele kui teise keele oskuse tase on väga varieeruv. Põhikooli lõpueksamil saavutavad B1-keeleoskustaseme ligikaudu 90\% keelekümblusklassis õppinutest ning umbes $60 \%$ tavaklassis õppinutest (Selliov 2016; EIS). B1-tase on seejuures vaid iseseisva keelekasutaja madalam tase. Sageli arvavad õpetajad, et nõrga eesti keele oskuse põhjuseks on madal õpimotivatsioon, mis tuleneb kodust ja ühiskonnast ehk kultuurikontekstist (Metslang jt 2013). Lisaks kultuurikontekstile on õppeprotsessile ja õpitulemustele aga suur mõju ka hariduskontekstil, sh kõigel, mis eesti keele tundides toimub. Õpilastele mõjuvad seejuures erisugused tegurid, mis võivad olla sõltuvalt olukorrast nii motiveeriva (õppima tõukava) kui ka demotiveeriva (õppimisest eemale tõukava) mõjuga. Nii motivatsioon kui ka demotivatsioon on eesti keele tunnis loomulikud protsessid. Nende tekkemehhanisme ja neid mõjutavaid tegureid on aga vaja hästi tunda, et suuta neid mõjutada õppetöö tõhustamise suunas. Käesoleva artikli aluseks on Monika Sooalu magistritöö (2016). Artiklis vaadeldakse, millised on peamised demotiveerivad tegurid üheksanda klassi õpilaste eesti keele kui teise keele tundides.

\section{Motivatsioon ja demotivatsioon teise keele õppes}

Teise keele omandamist mõjutavad paljud tegurid (autentse sisendi ja väljundi hulk, õppija vanus, õpistiil, keeleanne, isikuomadused jpm). Kõige olulisemaks teise keele omandamise määrajaks võib aga pidada motivatsiooni (Ellis 1994; Gardner 2007; Dörnyei \& Csizer 1998). Praegusaegsete sotsiaal-kognitiivsete motivatsiooniteooriate järgi mõjutavad motivatsiooni inimese mõtted ja tunded, mis tekivad suheldes teiste inimestega ja nende eeskujul (Ryan 2012). Teise keele õppimise motivatsioon võib olla sisemine (ingl intrinsic orientation) või väline 
(ingl extrinsic orientation, Ryan \& Deci 2000), integratiivne (ingl integrative motivation) või instrumentaalne (ingl instrumental motivation) (Gardner 1985). Kui motivatsioon on vähene või puudub, siis teist keelt ei omandata, isegi kui kõik muud tegurid on selle jaoks soodsad (Dörnyei \& Csizer 1998).

Motivatsioon ei ole püsiv nähtus, vaid tõusude ja langustega protsess (Dörnyei \& Ushioda 2011). Gardneri (2007) järgi mõjutab teise keele ópimotivatsiooni kultuurikontekst ja hariduskontekst. Kultuurikontekst tähendab keeleõppijat igapäevaelus ümbritsevat keskkonda: õpitava keele prestiiži, kasutusvõimalust ja -vajadust, kaaslaste suhtumist õpitavasse keelde, õpitava keele kogukonna suhtumist keeleõppijatesse jmt. Kultuurikontekst mõjutab seda, kui avatud on keeleõppija õpitava keele suhtes. Hariduskontekstil ehk koolisüsteemil on aga samuti roll teise keele õpimotivatsiooni määrajana. (Gardner 2007) Kõige enam mõjutab õpilaste motivatsiooni seejuures tundides toimuv: õpetaja käitumine, tunnis valitsev õhkkond, õppematerjali ja õppetegevuste tase jmt. Kõik nimetatud tegurid on eri tugevusega motivaatorid, mis soodsate tingimuste korral tekitavad, säilitavad ja suurendavad keeleõppija motivatsiooni ehk tõukavad teda teist keelt õppima ja omandama. Samas võivad samad tegurid ebasoodsate tingimuste korral muutuda vastandsuunalisteks ja hakata õpilasel olemasolevat motivatsiooni vähendama. Seda protsessi nimetatakse demotivatsiooniks (ingl demotivation) ja seda esilekutsuvad tegurid on demotivaatorid. (Dörnyei 2001a, 2001b; Kikuchi 2015)

Demotivatsioon ei tähenda õppija motivatsiooni täielikku kadumist. Kui ebasoodsad tegurid kaovad või muutuvad soodsateks, võib motivatsioon hakata jälle tõusma (Dörnyei 2001a). Kui demotiveerivaid kogemusi tekib aga palju, võib selle tulemusena kujuneda välja ka amotivatsioon (ingl amotivation) ehk motivatsiooni täielik kadumine (Brophy 2014; Dörnyei 2001b; Kikuchi 2015).

Demotivatsiooni teise keele tundides on maailmas uuritud eri meetodeid kasutades. Likerti tüüpi küsimustikega on lastud hinnata erisuguseid teise keele õppimist puudutavaid tegureid (Dörnyei 1998; Hamada \& Kito 2008; Bekleyen 2011; Zhang 2007). Suulistes intervjuudes (Dörnyei 
1998) ja kirjalikes esseedes (Oxford 1998; Muhonen 2004) on palutud óppijail kirjeldada oma teise keele õppimise ebamugavaid, ebameeldivaid, konfliktseid vmt kogemusi.

Uuringud on näidanud, et õpilasi demotiveerivad tegurid on enamasti seotud õpetaja, õppemeetodite ja õppematerjalidega. Kõige olulisem õpilasi demotiveerida võiv tegur on õpetaja (Dörnyei 1998; Muhonen 2004). Küllalt sageli on õpilased tunnetanud demotiveerivana õpetaja õpetamisstiili sobimatust endale või kahtlusi õpetaja pädevuse osas (Muhonen 2004; Kikuchi \& Sakai 2009; Hamada \& Kito 2008; Kikuchi 2015). Konkreetsemalt on õpilaste õpisoovi vähendanud näiteks nende arvates liiga kiire tunnitempo (Hamada 2008), tundide ebahuvitavus (Zhang 2007) ja seletuste arusaamatus (Kikuchi 2015; Zhang 2007). Õpilastele mõjub demotiveerivana ka õpetaja liigne rangus, kriitilisus ja vähene hoolivus (Hamada 2008; Zhang 2007; Oxford 1998), erapoolikus ja konfliktid õpilastega (Kikuchi 2015; Kikuchi \& Sakai 2009; Muhonen 2004; Oxford 1998). Õppimissoovi vähendab ka õpetaja entusiasmi puudumise ja ükskõiksuse tajumine (Oxford 1998; Muhonen 2004). Mitu korda on demotiveerivana välja toodud ka õpetajate sagedast vahetumist (Dörnyei 1998; Muhonen 2004).

Õppetegevuste osas on õppijaile demotiveerivalt mõjunud nende elukaugus (Kikuchi \& Sakai 2009). Mitmes uuringus on õppimissoovi vähendavana esile kerkinud ka keeletundide liigne grammatikakesksus ja vähene suhtlusvõimaluste hulk (Hamada \& Kito 2008; Kikuchi 2015; Bekleyen 2011). Ka tundide monotoonsus ja igavus, liiga suur koormus ning eksamidrill on demotivaatoriteks (Kikuchi \& Sakai 2009; Oxford 1998; Hamada 2008). Õpilaste hinnangud konkreetsete õppetegevuste kohta on seejuures olnud küllalt erisugused - see, mis ühtedele on olnud demotiveeriv, on mõnikord teistele meeldinud (Muhonen 2004).

Uuringutest on selgunud, et ka õppematerjalide mõju õpimotivatsioonile on suur. Õpikud mõjuvad demotiveerivalt, kui need ei vasta õppijate tasemele: on nende jaoks üleliia rasked või liiga kerged; igavad, lapsikud või vananenud (Bekleyen 2011; Hamada \& Kito 2008; Kikuchi \& Sakai 2009; Kikuchi 2015; Muhonen 2004). 
Demotiveerivad tegurid võivad olla eri õppijaile ka eri mõjuga. Mõne õppija motivatsioon väheneb pärast selliste teguritega kokkupuutumist, samal ajal kui mõnda teist õppijat need väga tugevalt ei mõjutagi. J. Muhoneni (2004) uuringust tuli näiteks välja, et eriti demotiveerivad olid õpetajaga seotud tegurid väga heade õpitulemustega õpilastele, kellest koguni $75 \%$ pidas õpetajat kõige demotiveerivamaks teguriks. Samast uuringust selgus ka, et poiste jaoks olid mitmed tegurid demotiveerivamad kui tüdrukute jaoks, nt ebasobiv õppematerjal oli nende jaoks kaks korda demotiveerivam (Muhonen 2004). Uuringutes on ka näidatud, et demotivatsioon esineb õppeprotsessis mingil määral ka siis, kui õpetaja püüab õpilaste motivatsiooni igati toetada ja demotiveerivaid tegureid vältida (Kikuchi 2015).

Kokkuvõtteks võib öelda, et teise keele õpimotivatsioon sõltub paljudest teguritest, mille hulgas ei tohi alahinnata hariduskonteksti ja eriti konkreetsetes tundides toimuva rolli. Teise keele õppimist mõjutavate demotiveerivate tegurite uurimine on oluline eelkõige selleks, et neid teadvustada ja leida võimalusi nende mõju vähendamiseks.

\section{Valim ja uurimismetoodika}

Käesoleva artikli aluseks olnud uuringu eesmärk oli välja selgitada üheksanda klassi óppijaid demotiveerivad tegurid eesti keele kui teise keele tunnis ning võrrelda, kuidas tajuvad samu tegureid nende õpilaste eesti keele kui teise keele õpetajad.

Uurimisküsimustele vastuse leidmiseks viidi läbi individuaalsed poolstruktureeritud intervjuud 20 üheksandas klassis eesti keelt kui teist keelt õppiva õpilasega (10 poissi ja 10 tüdrukut) ja nelja eesti keele kui teise keele õpetajaga. Õpilased olid pärit neljast erinevast Tallinna linna vene õppekeelega koolist (igast koolist viis õpilast) ja õpetajad olid nende õpilaste õpetajad (igast koolist üks õpetaja). Koolid valiti juhuslikult ja intervjueeritavad õpetajad valis kooli õppealajuhataja üheksandas klassis õpetavate õpetajate hulgast. Kaks õpetajat olid eestlased ja kaks venelased. Õpetajad omakorda valisid intervjueeritavad õpilased nii, et nende 
hulgas oleks nii poisse kui tüdrukuid ja õpilased oleks erineva eesti keele oskusega, kuid mitte amotiveeritud. Kõigi intervjueeritud õpilaste esimene keel oli vene keel ja õpilased ei olnud käinud eestikeelses lasteaias ega õppinud keelekümblusklassis. Intervjuud olid vabatahtlikud.

Intervjuu koosnes temaatilistest plokkidest: 1) kontakti loomine, 2) küsimused õppeteemade ja -tegevuste kohta, 3) küsimused õpetajate kohta, 4) küsimused õpperühma kohta. Igas teemaplokis olid poolstruktureeritud küsimused. Intervjuus esitati nii suletud kui ka avatud küsimusi vastavalt vestluse kulule. Intervjuu ühe isikuga kestis umbes üks tund. Õpetajate ja kolme õpilasega (kelle eesti keele oskus oli selleks piisav) viidi intervjuu läbi eesti keeles. Ülejäänud õpilastega viidi intervjuu läbi vene keeles ja tõlgiti pärast eesti keelde.

Intervjuud toimusid vaba vestluse vormis, intervjueeritavatele esitati küsimusi nii positiivsete kui seejärel ka negatiivsete kogemuste kohta, näiteks küsiti õpilastelt kontakti loomise plokis: Mis on sinu lemmiktunnid koolis? Miks need ained sulle meeldivad? Kuidas sulle eesti keele óppimine meeldib? Kas see on pigem kerge või pigem raske?; õppetegevuste plokis: Mida te tavaliselt eesti keele tunnis teete? Mis teemasid te eesti keele tunnis õpite? Nimeta mõni. Millised õppetegevused sulle eesti keele tunnis meeldivad? Millised óppetegevused sulle eesti keele tunnis ei meeldi? Palun kirjelda mõnd juhtumit, kus te tegite midagi sellist, mis sulle üldse ei meeldinud ja sa ei tahtnudki kaasa teha. Õpetajatelt küsiti kontakti loomise plokis nt Kui kaua te olete selles koolis ópetanud? Kas teile meeldib teie töö?; óppetegevuste plokis: Mis teemasid te ópilastele eesti keele tunnis ópetate? Kuidas need teemad neile meeldivad ja miks? Kuidas te tunnete, millised teemad ópilastele ei meeldi ja miks? Rääkige mõnest teemast, mis on õpilastelt óppimistuju ära võtnud. Tooge mõni konkreetne näide.

Intervjueeritud õpilaste ja õpetajatega saadi hea kontakt ja intervjuud sujusid hästi. Õpilased vastasid üldiselt küsimustele hea meelega. Mõnele küsimusele vastamisel oli siiski tunda, et see ei olnud kõigile õpilastele meeldiv, peamiselt olid need küsimused seotud õpetajaga. Õpilaste vastused varieerusid mahu ja sisukuse osas. Õpetajad rääkisid üldiselt palju, kuid kippusid vahel ka teemast kõrvale kalduma. Samuti 
oli kohati tunda, et õpetajatele oli mõnevõrra harjumatu analüüsida õppetegevuste mõju õpimotivatsioonile ja enda rolli õpiõhkkonna ning rühmaatmosfääri kujundamisel.

Intervjuude tekstid kirjutati maha, leiti nendest kõik õppimistuju vähenemisega seotud ütlused ning kodeeriti need. Koodid määrati deduktiivse ja induktiivse lähenemise koosmõjus. Lähtuti intervjuu jaoks loodud kolmest suurest tegurite rühmast: õppeteemade ja -tegevustega seotud tegurid, õpetajaga seotud tegurid ja õpperühmaga seotud tegurid. Seejärel uuriti iga rühma tegureid, rühmitati need sarnasuse alusel ja nimetati. Uuringu eesmärk oli otsida kõiki demotiveerivaid tegureid, mis eesti keele kui teise keele tunnis võivad esineda. Uuringu eesmärk ei olnud teha kvantitatiivset kokkuvõtet eri tegurite esinemissageduse ega seotuse kohta eri vastajatega. Õpilaste intervjuude analüüsi kirjelduses on kohati siiski kasutatud määratlusi: enamik vastajatest, korduvalt vastati, üle poole vastajatest, mitu vastajat, mõni vastaja, üks vastaja jmt. Õpetajate intervjuude analüüsis on mõnikord nimetatud, mitu õpetajat ühel või teisel viisil vastas.

\section{4. Üheksanda klassi õpilasi eesti keele kui teise keele tunnis demotiveerivad tegurid}

Intervjuude analüüsimisel selgus 16 peamist demotiveerivat tegurit, mis jagunevad kolme rühma: õppeteemadest ja -tegevustest tulenevad, õpetajast tulenevad ja õpperühmast tulenevad tegurid. Järgnevalt on tegureid vaadeldud rühmade kaupa.

\section{1. Õppeteemadest ja -tegevustest tulenevad demotivatsiooni tegurid}

Õpilaste intervjuudest selgus viis õppeteemadest ja -tegevustest tulenevat demotivatsiooni tegurit, millest õpetajate intervjuudes esines kolm (vt tabelit 1). 
TABEL 1. Óppeteemadest ja-tegevustest tulenevad demotivatsiooni tegurid õpilaste ja õpetajate hinnangul

\begin{tabular}{|l|l|}
\hline Õpilaste hinnangud & Õpetajate hinnangud \\
\hline 1. Õpitavate teemade ebahuvitavus & 1. Õpitavate teemade ebahuvitavus \\
2. Opppetegevuste ebahuvitavus & 2. Opppetegevuste ebahuvitavus \\
3. Õpitava raskus & 3. Oppitava raskus \\
4. Oppitava mittevajalikkus & 4. - \\
5. Ôpitava liigne maht & 5.- \\
\hline
\end{tabular}

\subsection{1. Õpitavate teemade ebahuvitavus}

Nii õpilaste kui ka õpetajate intervjuudes esines demotiveeriva tegurina õpitavate teemade ebahuvitavus. Enamik õpilastest hindab õpitavate teemade huvitavust erisuguseks, ühed teemad on nende sõnul huvitavamad ja teised igavamad ning õppimistuju võtavad ära igavad teemad. Mitmed õpilased peavad aga õpitavaid teemasid valdavalt igavaks. Kõnekas on fakt, et suur osa intervjueeritud õpilastest ei mäleta ühtegi teemat, mida eesti keele tunnis õppinud ollakse.

(1) Üks kord kuus teeme midagi huvitavat. (õpilase arvamus)

(2) Tekstid on igavad. Uut infot ei ole. Tuju õppida kaob. (õpilase arvamus)

Igavaks peavad õpilased teemasid, mis ei ole neile lähedased - õpilased tunnevad sel juhul, et teema pole neile ka vajalik. Tuuakse välja ka huvitavuse seos mõistetavusega. Kui teema ei ole arusaadav, siis muutub see ka igavaks.

(3) Teemal, mis huvitab, on mida rääkida. Kui teemast midagi ei tea, ei ole huvitav ja on raske rääkida. (õpilase arvamus)

Mitu õpilast avaldas arvamust, et õpitavate teemade huvitavus sõltub õppematerjalist. Osa õpilastest pidas õpikutekste üldiselt üsna huvitavaks, teised aga hindasid õppematerjale ebahuvitavaks.

(4) Ei meeldi vanad õppematerjalid. Ei taha nende järgi õppida. (õpilase arvamus) 
Igavana tuuakse välja ka pidevat eksamiteemadega tegelemist, mille vajalikkust küll mõistetakse, kuid mis siiski vähendab õpisoovi.

(5) Kõik on seotud eksamiülesannetega. Ka sügisel. (õpilase arvamus)

Kokkuvõttes on käsitletavate teemade ebahuvitavus õpilasi selgelt demotiveeriv tegur.

(6) Õppimistuju on kadunud, kui on igav. (õpilase arvamus)

Õpetajad tajuvad õpitavate teemade ebahuvitavust õpilastest erinevalt. Kaks õpetajat ei saa üldse aru, et mõni teema võib õpilastele ebahuvitav tunduda. Nende õpetajate hinnangul sõltub teema huvitavus või ebahuvitavus peamiselt viisist, kuidas teemat õpetada. Tundub, et õpetajad ei mõtlegi enamasti teema huvitavusele, vaid nende peaeesmärk on, et õpilased ettenähtud ülesanded lihtsalt ära teeksid.

(7) Ei ole selliseid teemasid, oluline on, kuidas õpetada. (õpetaja arvamus)

(8) Ei ole selliseid teemasid, mis õpilastele ei meeldi. Õpilased teevad need lihtsalt ära. (õpetaja arvamus)

Kaks õpetajat mainivad siiski, et mõni teema võib õpilastele vähem huvi pakkuda. Näiteks tuuakse välja eesti kirjanduse ja ajalooga seotud teemade ebahuvitavust. Õpetajate arvates sõltub teemade huvitavus ka õpilastest: osale õpilastest meeldivad paljud teemad, teistele aga ei meeldi midagi.

(9) See oleneb seltskonnast, osadele särasilmsetele meeldib, osad jälle leiavad, et see on nendele tüütu. (õpetaja arvamus)

Kõik neli küsitletud õpetajat jagavad aga arvamust, et koolis kasutatavad eesti keele õpikud on õpilastele ebahuvitavad. 


\subsection{2. Õppetegevuste ebahuvitavus}

Õppetegevuste ebahuvitavust peavad demotiveerivaks nii õpilased kui ka õpetajad. Enamik õpilastest väidab, et eesti keele tundides loetakse põhiliselt tekste ja tõlgitakse neid, täidetakse lünkharjutusi, kirjeldatakse pilte, koostatakse dialooge ja kirjutatakse kirju sõbrale ehk tehakse eksami tüüpi ülesandeid. Õpilased peavad ühetaolisi õppetegevusi igavaks ja väidavad, et need kahandavad nende õppimissoovi. Umbes pooled õpilastest tunnevad aga, et eksami tüüpi ülesanded on vaatamata igavusele vajalikud.

(10) Teeme ainult eksamiülesandeid, igav, ühekülgne. (õpilase arvamus)

(11) Kui me proovime eksamitööd teha, ei taha ma mõnikord teha, sest tahan midagi muud teha, mul pole tuju seda teha. (õpilase arvamus)

Kaks õpetajat jagab õpilaste arvamust eksamiks harjutamise igavuse kohta. Samas ei näe nad sellele ka alternatiivi, sest eksamiks harjutamine on nende meelest hädavajalik.

(12) Teeme tunnis ainult eksamiülesandeid, ópilastel on raske ja igav, kuid neil pole valikut. Nad peavad eksami ära tegema. (õpetaja arvamus)

(13) Ega kui me ikka näiteks hakkame kahekümnendat korda kirja kirjutama, ei ole see mingi "hurraa", siis on ikkagi "oh jumal, jälle". (õpetaja arvamus)

\subsection{3. Õpitava raskus}

Kolmandaks demotiveerivaks teguriks on nii õpilaste kui ka õpetajate arvates õpitava raskuse tunnetamine. Paljud intervjueeritud õpilased väidavad, et eesti keele õppimine on keerukas, seejuures valmistavad neile aga raskusi eri aspektid.

Kõige rohkem nimetavad õpilased keerulisena eesti keele grammatikat. Sageli nimetatakse grammatikat tervikuna keeruliseks, põhjusena tuuakse seejuures esile vene keelest erinemine ja rohkete erandite esinemine. 
(14) Ei meeldi grammatikareegleid kirjutada. Ei saa aru. (õpilase arvamus)

(15) Keeruline, sest erineb vene keelest, palju tuleb meelde jätta. (õpilase arvamus)

(16) Ei meeldi siis, kui tean, et on vaja seda käänet kasutada, aga tegelikult selles kohas peab teist käänet kasutama, sest on erandid. (õpilase arvamus)

Mõni keeruline teema tuuakse ka eraldi välja.

(17) Ei taha käändeid õppida, sest raske, üldse ei saa aru, kuidas kasutada. (õpilase arvamus)

(18) Ei meeldi omastav ja osastav - liiga rasked. (õpilase arvamus)

(19) Ei meeldi ma- ja da-infinitiiv, ei saa aru. (õpilase arvamus)

Korduvalt nimetatakse raskena ka kirjutamist. Põhjustena nimetavad õpilased seejuures nii oma väikest sõnavara, nõrku grammatikateadmisi kui ka kirjutamisülesande teema mittevaldamist. Üks õpilane mainib ka oskamatust luua kirja struktuuri.

(20) Ei meeldi kiri, sest sõnavara on väike, sõnade otsimine võtab palju aega. (õpilase arvamus)

(21) Kurb, kui õigesti ei saa lauseid moodustada. (õpilase arvamus)

(22) Kiri ei meeldi, kui on keeruline teema, mida ei tunne. (õpilase arvamus)

Veerand intervjueeritud õpilastest pidas raskeks kuulamisülesandeid. Põhjuseks peetakse teksti liigset kiirust.

(23) Kuulamine on raske, ei jõua kuulata, lasen kõrvust mööda. (õpilase arvamus)

Rääkimist peetakse raskeks kõige vähem, kuid kui ei tea, millest rääkida, võib siiski ka rääkimine raskusi valmistada. Lugemise teevad raskeks pikad tekstid ja suur tundmatute sõnade hulk. Sõnade õppimise juures tuuakse raskusena välja sõnade mittemeeldejäämist. Mitme õpilase 
jaoks on rasked ja ebameeldivad kõik mahukad ülesanded, mis nõuavad ise mõtlemist.

(24) Õppimise tuju võtavad ära koduülesanded, mis on pikad, rasked, näiteks pikk tekst tõlkida, sõnu pole sõnaraamatus. (õpilase arvamus)

(25) Näiteks anti kodus tõlkida tekst - terve õhtu tõlkisin, vanemad aitasid. (õpilase arvamus)

Õpitava raskuse kohta avaldavad ka õpetajad palju arvamusi. Ka õpetajate hinnangul on eesti keele grammatika õpilastele raske.

(26) On keeruline ja raske õppida, sellepärast, et on palju nüansse, millele tähelepanu pöörata. (õpetaja arvamus)

(27) Täpne grammatika on väga raske. (õpetaja arvamus)

Õpilaste jaoks kõige raskemaks peavad õpetajad kirjutamist. Põhjusena tuuakse õpilaste nõrka grammatikaoskust, sõnavara piiratust ja ka vähest mõtlemisoskust. Kuulamise teeb õpetajate arvates õpilastele raskeks samuti vähene grammatika tundmine, seda eriti juhul, kui kuulamisülesande vastus tuleb ise kirja panna. Kolm õpetajat arvavad, et õpilastele ei meeldi ka lugeda.

(28) Praegusel õpilasel on äärmiselt raske pikemat teksti lugeda, see nõuab kontsentreerumist, mida ta ei suuda väga lihtsalt tunnis teha. Ta ei ole harjunud, üldjuhul ei loe ta pikemaid tekste enam ka emakeeles. (õpetaja arvamus)

Intervjueeritud õpetajad olid ühel meelel, et õppijatele ei meeldi kodused ülesanded - põhjuseks peetakse õpilaste laiskust. Kõik õpetajad jagavad ka arvamust, et õpilastele ei meeldi ülesanded, mis nõuavad mõtlemisoskust.

Kolm õpetajat toovad ka õpitava raskusest rääkides välja rahulolematuse õppematerjalidega.

(29) Äärmiselt ebakvaliteetne õppematerjal: ei anna baassõnavara, ei anna grammatikapõhja, ei suhtlusoskust, ei kuulamisoskust, ühesõnaga, selles töövihikus ja õpikus ei ole mitte midagi. (õpetaja arvamus) 
(30) Õppematerjalid ei meeldi: keerulise ülesandepüstitusega pikad tekstid, äärest ääreni täis kirjutatud, ilma illustreerimata. (õpetaja arvamus)

\subsection{4. Õpitava mittevajalikkus}

Õpitava mittevajalikkuse tunnetamine on demotiveeriv tegur õpilaste arvates. Õpilased mainivad, et nende õppimistuju vähendab see, kui nad peavad tegema harjutusi, mis ei anna eluks vajalikke oskusi.

(31) Mul pole elus seda vaja, mul on vaja uusi sõnu ja vorme, aga mitte šabloonküsimusi. (õpilase arvamus)

Korduvalt nimetasid õpilased ebavajalikuna töövihikuharjutusi, mis nõuavad vaid automaatset harjutuste täitmist ega arenda tegelikku keeleoskust.

(32) Tuju võtavad ära töövihikuharjutused, sest ma ei näe sellel mingit mõtet - lihtsalt kirjutada vastuseid, eesti keelt sellega eriti ei õpi. (õpilase arvamus)

(33) Sa ei pea midagi mõtlema, lihtsalt automaatselt kirjutad sõnu lünkadesse. (õpilase arvamus)

Mitu õpilast pidas õppimistuju vähendavaks ka tekstide ja reeglite päheõppimist ning kodutööde tegemist.

Õpetajad õpitava mittevajalikkuse kohta arvamust ei avaldanud.

\subsection{5. Õpitava liigne maht}

Õpitava liigne maht on demotiveeriv ópilaste arvates. Intervjueeritud õpilased märkisid korduvalt, et õpituju võtab ära see, kui õppematerjali läbitakse liiga kiiresti ja õppida antakse korraga liiga palju.

(34) Ei meeldi liiga palju uusi sõnu või liiga palju uut infot korraga. (õpilase arvamus)

(35) Liiga pikad tekstid, pole eakohased. (õpilase arvamus)

(36) Õpime uut teemat ja juba järgmine päev on töö. (õpilase arvamus) 
MIKS MÕNIKORD KAOB TUJU EESTI KEELT ÕPPIDA?

Üle poole õpilastest toob eraldi välja ka koduülesannete liigse rohkuse.

(37) Koduülesanded võtavad palju aega. Me oleme noored, tahame elada, muuga tegelda. (õpilase arvamus)

(38) Koolipäevad on liiga pikad, tuleme koju - läheme trenni, muusikakooli. Kui koju jõuame, oleme väsinud ja siis vaatad - oi, kui palju kodutöid, vaatan kella, kell on nii palju, ei jõua neid ära teha - ja ei tee neid kodutöid. (õpilase arvamus)

Õpetajad õpitava liigse mahu kohta arvamust ei avaldanud.

Kokkuvõttes võib õppeteemade ja -tegevuste kohta öelda, et nende mõju õpilaste demotivatsioonile on suur. Esiteks mõjub demotiveerivalt igavus, see kehtib nii õpitavate teemade kui ka tunnis kasutatavate õppetegevuste kohta. Igavad teemad on need, mis ei ole õpilastele lähedased ega arusaadavad. Igavate õppetegevustena kerkis selgelt esile sage eksamitüüpi ülesannete harjutamine. Ka õpitava raskuse ja mittevajalikkuse tunnetamine ning ülesannete liigne maht kahandavad õpilaste õpisoovi.

Õpetajad märkavad õpilastest vähem, mis võib õpilasi õppeteemade ja -tegevuste juures demotiveerida. Peamiselt saavad õpetajad aru õpitava raskuse võimalikust negatiivsest mõjust. Õppetöö huvitavusele on nad vähem mõelnud ja kui ongi, siis ei näe igavatele tegevustele sageli alternatiivi, sest peavad neid hädavajalikuks. Õppetöö kohatise igavuse ja raskuse üheks peapõhjuseks peavad õpetajad üsna üksmeelselt kehvi õppematerjale. Nimetatakse ka mõne õpilase laiskust ja mitte millegi vastu huvi tundmist.

\section{2. Õpetajast tulenevad demotivatsiooni tegurid}

Õpilaste intervjuudest selgus seitse õpetajast tulenevat demotivatsiooni tegurit, millest õpetajate intervjuudes esines kolm (vt tabelit 2). 
Tabel 2. Õpetajast tulenevad demotivatsiooni tegurid ópilaste ja ópetajate hinnangul

\begin{tabular}{|l|l|}
\hline Õpilaste hinnangud & Õpetajate hinnangud \\
\hline 1. Õpetaja ebasõbralikkus & 1. - \\
2. Õpetajast mittearusaamine & 2. Ôpetajast mittearusaamine \\
3. Kartus & 3. Kartus \\
4. Õpetaja ebaõiglane suhtumine & 4. - \\
5. Oppilaste sundimine & 5. - \\
6. Õpetajapoolne vähene tähelepanu & 6. Õpetajapoolne vähene tähelepanu \\
7. Õpetaja mittesobiv õpetamisstiil & 7. - \\
\hline
\end{tabular}

\subsection{1. Õpetaja ebasõbralikkus}

Õpilaste intervjuudest kerkis demotiveeriva tegurina selgelt esile õpetaja ebasõbralikkus. Eriti demotiveerivana tajuvad õpilased seda, kui õpetaja nende peale karjub või nendega riidleb.

(39) Õppimistuju on läinud, kui õpetaja karjub, et me ei saa aru. (õpilase arvamus)

(40) Kui proovisime tasemetööd kirjutada, hakkas õpetaja riidlema - miks teed vigu, kui sa oskad. Pärast ei tahtnud ma tema tundi minna. (õpilase arvamus)

Ka lihtsalt õpetaja halb tuju mõjub õpilastele demotiveerivalt. Mõni õpetaja on õpilaste arvates kogu aeg ebasõbralik ega naerata kunagi.

(41) Ei saa aru, mis tujus ta on, pigem kogu aeg halvas tujus. (õpilase arvamus)

Õpilaste hinnangul võib õpetaja halb tuju olla põhjustatud õpilastest, kes ei tööta tunnis kaasa, või mõnikord ka koolivälistest teguritest.

(42) Vahel on õpetaja halvas tujus, kui meil puudub huvi. Meile ei meeldi, et siis saab ta vihaseks ja annab hindele ülesande teha. (ópilase arvamus) 
(43) Õppimistuju kaob, kui õpetajal on kodus probleemid ja ta valab oma halva tuju meie peale välja. (õpilase arvamus)

Õpetajad oma tuju ja sõbralikkust üldjuhul ei kommenteerinud. Ainult kord toodi välja, et õpilaste aktiivsus-passiivsus mõjutab õpetaja tuju.

(44) Hästi mõjub siis, kui võtavad endale initsiatiivi: teeme täna nii, teistmoodi. See innustab neid rohkem panustama, siis hakkan ise ressursse otsima, et neile pakkuda midagi kvaliteetsemat. Halvasti mõjub, kui nad ei reageeri. Küsid, mitte midagi, ta ei näita üldse emotsioone, ei saa aru, kas ta on pahane, kas talle meeldib. See viib mind endast täitsa välja. (õpetaja arvamus)

\subsection{2. Õpetajast mittearusaamine}

Õpetajast mittearusaamine esines enamiku intervjueeritud õpilaste vastustes demotiveeriva tegurina. Veidi puudutasid seda teemat ka õpetajad. Õpilased tõdesid, et nad ei saa alati hästi aru, mida õpetaja neile ütleb või mida neilt ootab, ning see alandab nende õppimissoovi. Mittearusaamise põhjusteks peavad õpilased enda tähelepanu hajumist või vähest keeleoskust ning õpetajapoolset ebaselget seletamist.

(45) Mõnikord ei saa aru õpetaja ootustest ja teed valesti. (õpilase arvamus)

(46) Vahel ei saa aru, kui õpetaja räägib eesti keeles. (õpilase arvamus)

(47) Ei meeldi see, kui õpetaja ei oska hästi teemat seletada. (õpilase arvamus)

Õpetajate hinnangul saavad õpilased neist üldiselt aru. Juhul kui aru ei saada, peavad õpetajad põhjuseks õpilaste tähelepanematust, arusaamissoovi puudumist ja arusaamatuste korral õpetaja mitteteavitamist.

(48) Õpilased saavad hästi aru. Juhtub, et ei saa aru, sest tähelepanu on kõrval olnud. (õpetaja arvamus)

(49) Kes tahab, saab minust aru, kes on trotsi täis, ei taha aru saada. (õpetaja arvamus)

(50) Probleem on, kui õpilased annavad vale tagasisidet - kui ütlevad, et saavad aru, aga tegelikult ei saa. (õpetaja arvamus) 


\subsubsection{Kartus}

Kartus tuli demotiveeriva tegurina esile nii õpilaste kui ka õpetajate intervjuudest. Mitu õpilast kardavad halbu hindeid ja märgivad, et halvad hinded langetavad nende õpimotivatsiooni.

(51) Kardan, et saan halva hinde. Halb hinne võtab õppimise tuju ära. (õpilase arvamus)

(52) Õpetaja ütles, et kodutööst sõltub minu veerandi hinne. Hakkasin kartma ega julgenud tundi minna. (õpilase arvamus)

Mõni õpilane ütles, et kui koolis hindeid ei pandaks, siis õpiksid nad paremini.

(53) Kui õpetaja hinnet ei paneks - õpiksin paremini, pööraksin tähelepanu sellele, mis välja ei tulnud ja pingutaksin. (ópilase arvamus)

Veel rohkem kui halbu hindeid kardetakse eksameid. Õpetajad hirmutavad õpilaste sõnul neid eksami raskuse ja eksamitulemuste mõjuga edasisele elule üsna sageli, eesmärgiga õpilasi rohkem õppima motiveerida. Õpilastele mõjub see sageli aga hoopis vastupidi.

(54) Õppimistuju kaob, kui meile rõhutatakse, et sa ei oska, et sa pead seda juba ammu oskama. Kardan, et ei tee eksamit ära. (õpilase arvamus)

Õpilased kardavad ka õppimise käigus vigu teha, sest neile on antud mõista, et see on väga halb, ja see mõjub samuti õppimistujule negatiivselt.

(55) Kui proovisime tasemetööd kirjutada, hakkas õpetaja riidlema - miks teed vigu, kui sa oskad, mul hakkas halb. (õpilase arvamus)

(56) Õpetaja peab meid tugevaks, sest kõik oskavad rääkida, aga kardavad oma vigu, öelda midagi valesti. Osad satuvad paanikasse. (õpilase arvamus)

(57) Õpetaja parandab vigu kohe, aga parem kui ta parandaks pärast rääkimist, sest kui ta parandab kohe - kardad edasi rääkida. (õpilase arvamus) 
Veel ühe hirmuna kerkib mõnikord esile kartus õpetajalt arusaamatuste korral selgitusi küsida.

(58) Ühe õpetajaga oli selline juhus, et ei julgenud midagi küsida, sest kõik töötasid ja jäi mulje, nagu kõik said aru, ainult mina ei saanud ega osanud teha, mul oli häbi küsida ja õpetaja oli liialt range. (õpilase arvamus)

Õpetajad avaldasid arvamust eksamihirmu ja negatiivse tagasiside mõju kohta. Eksamikartus võib nende arvates seejuures mõjuda nii õppima panevalt kui ka õppimissoovi vähendavalt.

(59) Kui eksamit poleks, õpiksid vähem, aga võib-olla ka rohkem, sest poleks hirmu. (õpetaja arvamus)

Üks õpetaja mainis ka hirmutamise rolli õpilaste motiveerimisel.

(60) Ütlen neile: "Kui ei tule midagi välja ja sa istudki siin lihtsalt selleks, et midagi välja ei tule - tulevikus saab sinust koristaja." (õpetaja arvamus)

Ka negatiivse tagasiside kohta arvasid õpetajad kahte moodi: see võib mõjuda nii motiveerivalt kui ka demotiveerivalt.

(61) Õpilane sai kriitilise tagasiside ja ütles, et ei hakka enam kunagi eesti keelt õppima. See võttis ta õppimistuju ära. (õpetaja arvamus)

(62) Õpilane sai objektiivse, kriitilise tagasiside, aga see mõjus talle positiivselt. Tema arvamus muutus, entusiasmi võttis vähemaks, aga ta võttis end kokku ja tulemus läks paremaks. (õpetaja arvamus)

\subsection{4. Õpetaja ebaõiglane suhtumine}

Kui õpilased tajuvad õpetaja ebaõiglast suhtumist enda suhtes, siis kahandab see nende õpituju tunduvalt. Esiteks tajuvad õpilased ebaõiglasena enda arvates vale hinde saamist.

(63) Ei meeldi, kui kerge vea eest hinnet alandatakse. (õpilase arvamus) 
(64) Näiteks valmistusin, jutustasin kiiresti - sain halvema hinde kui see, kes jutustas aeglaselt - õpetaja arvas, et mul oli lühem tekst. (õpilase arvamus)

Teiseks tajuvad õpilased ebaõiglasena, kui õpetaja ei kontrolli ega hinda tehtud kodutöid, ja eriti seda, kui kaaslastel on kodutöö tegemata ja seda hakatakse siis koos tunnis tegema.

(65) Tuju võtab ära see, kui mul on ainukesena kodune töö tehtud ja seda isegi ei kontrollita ja ma ei saa selle eest hinnet. Teised arvavad, et olen loll, et teen. (õpilase arvamus)

(66) Juhtub, et tuju läheb ära, kui nad ei tee kodutöid, mina aga tegin. Tunnis me siis teeme seda tööd, mis mul on juba tehtud. (õpilase arvamus)

Õpilased tajuvad väga ebaõiglasena ka seda, kui sama asja eest ühe õpilasega pahandatakse, aga teisega mitte.

(67) Istusin pinginaabriga, tegelesime ühe ja sama asjaga, aga riielda sain ainult mina - mul kadus õppimissoov. (õpilase arvamus)

Õpetajad ebaõigluse kohta arvamust ei avaldanud.

\subsection{5. Õpilaste sundimine}

Mitmeid kordi kerkis õpilaste intervjuudes demotiveerivana esile ka õpilaste sundimise küsimus. Õpilastele ei meeldi, kui neil ei lasta teha ülesandeid nende soovi järgi.

(68) Ei meeldi, kui õpetaja surub oma tahtmist peale. Peame tegema seda, mis ei meeldi. (õpilase arvamus)

(69) Kui õpetajale ei meeldi see, mida teen, kuna ei ühti tema arvamusega, mina aga olen sellega rahul. (õpilase arvamus)

Õpetajad õpilaste sundimise kohta arvamust ei avaldanud. 


\subsection{6. Õpetajapoolne vähene tähelepanu}

Mõni õpilane ja üks õpetaja tõid demotiveerivate teguritena välja ka asjaolu, et õpetaja pöörab õpilastele liiga vähe tähelepanu. Õpilaste hinnangul kahandab nende õpisoovi näiteks see, kui õpetaja eelistab oma väljakujunenud lemmikuid ja ignoreerib teisi õpilasi.

(70) Ei meeldi, kui õpetaja küsib ainult ühtesid ja samu õpilasi, kui õpetaja küsib, sa tead vastust, aga teine õpilane segab vahele ja õpetaja ei küsi mind rohkem. (õpilase arvamus)

(71) Ükskord ei teinud ma kolm tundi midagi, ta hakkas mind ignoreerima. Soov midagi teha kadus täiesti. (õpilase arvamus)

Õpetajatest mainis üks, et võib juhtuda, et mõni õpilane saab vähem tähelepanu, jääb varju ja arvab siis, et õpetaja ei mõista ega märka teda.

\subsection{7. Õpetaja mittesobiv õpetamisstiil}

Paar õpilast mainisid, et nende õpisoovi vähendab õpetaja ebasobiv õpetamisstiil. Õpilased pidasid häirivaks nii liialt pehmet kui ka liialt ranget õpetajat.

(72) Tunnis omandan vähe - kõik karjusid, ma ei kuulnud, õpetaja oli pehme, ta ei osanud klassi kontrollida, kõik segasid. (õpilase arvamus)

(73) Kui õpetaja ei oleks nii range, siis see stimuleeriks rohkem õppima. (õpilase arvamus)

Õpetajad ebasobiva õpetamisstiili teemat ei kommenteerinud.

Kokkuvõttes võib õpetajaga seotud tegurite kohta öelda, et nende hulgas on mitu sellist, mis võivad õpilasi tugevalt demotiveerida. Esiteks mõjub õpilastele halvasti õpetaja ebasõbralikkus (eriti karjumine ja pahandamine, aga ka lihtsalt halb tuju). Teiseks on óppimissoovi tugevalt kahandava mõjuga see, kui ei saada aru õpetaja seletustest või töökäskudest. Kolmandaks põhjustab demotivatsiooni kartus, kardetakse tunnis halba hinnet saada, eksamit kehvalt sooritada ja ka lihtsalt 
õppimise käigus vigu teha. Veel on demotiveeriv õpetaja ebaõigluse tunnetamine. Ôpetajad ei taju endaga seotud demotiveerivaid tegureid eriti selgelt. Näiteks arvavad nad, et õpilased saavad neist üldiselt aru ja kui ei saa, on selles ise süüdi. Osa õpetajatest arvab ka, et õpilaste hirmutamine on neile motiveeriv.

\section{3. Õpperühmast tulenevad demotivatsiooni tegurid}

Õpperühmast tulenevaid demotivatsiooni tegureid selgus neli, nii õpilased kui ka õpetajad rääkisid neist kõigist (vt tabelit 3).

Tabel 3. Õpperühmast tulenevad demotivatsiooni tegurid ópilaste ja ôpetajate hinnangul

\begin{tabular}{|l|l|}
\hline Õpilaste hinnangud & Õpetajate hinnangud \\
\hline 1. Halvad suhted kaaslastega & 1. Halvad suhted kaaslastega \\
2. Tunni segamine & 2. Tunni segamine \\
3. Kaasõpilaste passiivsus & 3. Kaasõpilaste passiivsus \\
4. Õpperühma ebaühtlane tase & 4. Õpperühma ebaühtlane tase \\
\hline
\end{tabular}

\subsubsection{Halvad suhted kaaslastega}

Suurem osa intervjueeritud õpilastest tõi demotiveeriva tegurina välja halvad suhted rühmakaaslastega. Eriti tugevalt vähendavad õppimissoovi kaaslaste negatiivsed kommentaarid. Sealhulgas kerkis eraldi esile vigade parandamise negatiivne mõju.

(74) Õpperühmas on õpilasi, kes teavad su nõrka kohta ja sobival ajal ütlevad midagi halvasti. Nad rikuvad tuju ja ma ei taha enam õppida. (õpilase arvamus)

(75) Klassikaaslased naeravad su üle, kui teed vea, ja sul kaob kogu huvi selle aine vastu. (õpilase arvamus)

(76) Tugevamad õpilased võivad hakata sinu vigu parandama. See häirib mind väga ja ma ei taha vastata. (õpilase arvamus) 
Õpimotivatsioonile võivad negatiivselt mõjuda ka klassisisesed grupid. Sealhulgas on mõnes klassis tavaks suhtuda tublimatesse õpilastesse halvasti.

(77) Kõik sõltub tujust - vahel on kõik hästi, valitseb selline tunne, et kõik on sõbrad. Peagi jagunetakse gruppidesse, mõnel on kummaline käitumine, mõnel ei ole sotsiaalseid oskusi. (õpilase arvamus)

(78) Tuju pole, kui kogu klassil on kodutöö või tunnitöö tegemata ja kõik vaatavad mind - oo, tegid ära!! Miks tegid? Nagu ma ei tohiks teha. (õpilase arvamus)

Õpetajad hindasid õpperühmade siseseid suhteid üldiselt heaks. Kaks õpetajat tõid siiski välja tõrjutud õpilaste olemasolu või arutlesid suhete olulisuse üle.

(79) On ka tõrjutuid. Tundlik vanus. (õpetaja arvamus)

(80) Nad on õrnas eas - lahkumised, tülid. Eraelu ja koolielu on raske eraldi hoida. (õpetaja arvamus)

(81) Juhuslikult öeldud fraas, mis ei kattu õpilase meeleoluga, võib tekitada õpilases tunde, et teised ei mõista teda. (õpetaja arvamus)

\subsubsection{Tunni segamine}

Veidi rohkem kui pooled õpilased märkisid, et tunni segamine võib samuti õppimistuju ära võtta. Sageli on ebasobivalt käitujad ehk tunni segajad õpilased, kes ei soovi eesti keelt õppida, sest ei kavatse oma tulevikku Eestiga siduda.

(82) Mõned segavad, tahavad olla tähelepanu keskpunktis, see on võtnud õppimistuju ära. (õpilase arvamus)

(83) Mitte kõik ei taha õppida, sest arvavad, et sõidavad välismaale. Nad ei õpi tunnis, vaid segavad. Sellised õpilased võtavad ka minul õppimistuju ära, sest nad ei lase õppida. (õpilase arvamus)

Õpilased oskavad ka ise märgata, et väsimus mõjutab nende käitumist mõnikord negatiivselt. 
(84) Vahel käituvad õpilased rahulikult - kui tund on päeva esimeses pooles, kui tund on päeva teises pooles, siis lobiseme palju. (õpilase arvamus)

Kaks õpetajat tunni segamist probleemina ei näe. Kaks õpetajat mainib, et mõnikord tuleb ette, et mõni õpilane tundi segab.

(85) Töötavad hästi kaasa, aga segavad ka. (õpetaja arvamus)

(86) Kui peavad kontsentreeruma, ja keegi õpilane segab, siis on see kohe näha. (õpetaja arvamus)

\subsubsection{Kaasõpilaste passiivsus}

Õpilaste hinnangul on nende õpperühmades passiivseid õpilasi pigem rohkem kui aktiivselt tunnis osalevaid. Passiivsuse peapõhjusteks peeti vähest eesti keele oskust ja sellest tulenevat raskust tunniülesannete täitmisel, aga ka tunni igavust. Kaaslaste passiivsus võib olla väga demotiveeriv.

(87) Mõned lihtsalt istuvad, õpetaja ütleb, miks sa pole aktiivne, aga neid ei huvita. (õpilase arvamus)

(88) Õpilased on passiivsed ja see on äärmiselt väsitav, võib hulluks minna. (õpilase arvamus)

Enamik õpetajatest peab õpilasi pigem passiivseteks kui aktiivseteks. Õpetajad märkisid ka, et õpilaste poolt sõnades väljendatu ja tegevused lähevad sageli vastuollu.

(89) Räägivad, et tahavad õppida, aga ei õpi. (õpetaja arvamus)

(90) Paljud on öelnud, et eesti keel on nende lemmiktund, aga teisest küljest ei viitsi nad õppida. (õpetaja arvamus)

Kaks õpetajat ei oska passiivsuse põhjust välja pakkuda, kaks õpetajat peab selleks laiskust, muid huvisid või oma tuleviku Eestiga mittesidumist. 


\subsection{4. Õpperühma ebaühtlane tase}

Paar korda ütlesid intervjueeritud õpilased, et nende õppimistuju mõjutavad negatiivselt nõrga keeleoskusega rühmakaaslased.

(91) Õppimistuju võtab ära, kui õpilane on 9. klassis, aga ei tea elementaarseid asju. See ärritab mind. (õpilase arvamus)

Õpetajad näevad samuti õpperühma ebaühtlases tasemes probleemi.

(92) Ei meeldi, et rühm on natuke tasakaalust väljas. Mõned on tugevad, nõrgad jäävad nende varju. Nõrkadel on häbi, et ei oska. Samas pole nõrkadel ikkagi soovi - keel ei meeldi neile ja nad ongi teadlikult nõrgad. (õpetaja arvamus)

Kokkuvõttes võib õpperühmaga seotud tegurite kohta öelda, et ka neil on õpilaste õppimissoovile tugev mõju. Eriti mõjutavad õpilasi omavahelised suhted. Kui suhted on halvad, on sellel tugev demotiveeriv mõju. Õppimissoovi vähendavalt mõjub ka kaasõpilaste passiivsus ja tunni segamine. Õpetajad näevad õpperühmaga seotud tegurite mõju väiksemana kui õpilased.

\section{Kokkuvõte ja arutelu}

Käesolev uuring oli esimene katse uurida eesti keele tunnis õpilastele mõjuvaid demotiveerivaid tegureid. Õpilaste intervjuude analüüsil selgus 16 demotiveerivat tegurit, mis jagunesid kolme rühma: õpetajaga seotud, õppeteemade ja -tegevustega seotud ning õpperühmaga seotud tegurid. Õpetajate intervjuudes esines neist 10 ehk õpetajad ei olnud endale teadvustanud kõiki demotiveerivaid asjaolusid, mis õpilasi tundides potentsiaalselt mõjutavad.

Esiteks selgus uuringus, et õppeteemadel ja -tegevustel on õpilaste õppimissoovile oluline mõju. Demotiveerivalt mõjub õpilastele igavus. Igavaks peavad õpilased neile kaugeid ja arusaamatuid õppeteemasid ning ühetaolisi eksami tüüpi ülesandeid. Demotiveerivalt mõjub noortele ka see, kui nad tunnevad, et õpitav on neile raske ja mahukas ning samas 
kaheldava vajalikkusega. Õpetajad ei teadvusta endale sageli õppetöö huvitavuse olulisust õpimotivatsiooni kujundamisel. Neile on olulisem programmi läbimine ja õpilaste eksamiks ettevalmistamine. Õppetöö kohatisest raskusest saavad õpetajad paremini aru. Õppeteemade ja -tegevustega seotud probleemide põhjuseks peavad õpetajad üksmeelselt kehvi õppematerjale ja mõnikord ka laisku ja mittehuvitatud õpilasi.

Ka muudes riikides läbi viidud uuringutes on ilmnenud tundide igavuse, elukauguse, liiga suure koormuse ja eksamidrilli demotiveeriv mõju õpilastele (Kikuchi \& Sakai 2009; Hamada \& Kito 2008; Kikuchi 2015; Bekleyen 2011; Oxford 1998; Hamada 2008). Varasemates uuringutes on eraldi välja tulnud ka õppematerjalide oluline roll õpisoovi kujunemisel. Kui õpikud on tasemele mittevastavad, igavad, lapsikud või vananenud, siis vähendavad need tugevalt õpimotivatsiooni (Bekleyen 2011; Hamada \& Kito 2008; Kikuchi \& Sakai 2009; Kikuchi 2015; Muhonen 2004). Siinses uuringus ei uuritud õppematerjalide mõju eraldi. Siiski mainisid õpilased, et vananenud õppematerjalide järgi ei soovita õppida. Õpetajad mainisid seevastu õpikuid korduvalt ja pidasid nende kehva kvaliteeti mitmete eesti keele õppega seotud probleemide põhjuseks.

Teiseks selgus siinses uuringus õpetaja väga oluline roll eesti keele õppe motiveerivuses. Õpilased ootavad, et õpetaja oleks rahulik, sõbralik ja toetav ning igasugused vastupidised ilmingud vähendavad tõenäoliselt óppimissoovi. Samuti vajavad õpilased, et õpetaja suhtuks neisse mõistvalt ja õiglaselt. Mittemõistmist ja ebaõiglust tajutakse teravalt ja see mõjub samuti óppimissoovi vähendavalt. Veel on oluline, et õpilased saaksid aru õpetaja seletustest ja õpetaja ootustest enda suhtes. Kui seda ei ole, siis õpimotivatsioon kahaneb. Ka muude maade uuringutest on selgunud õpetaja määrav roll õpilaste demotivatsioonis. Sarnaselt siinsele uuringule on ilmnenud seletuste arusaamatuse (Kikuchi 2015; Zhang 2007), õpetaja liigse kriitilisuse ja vähese hoolivuse (Hamada 2008; Zhang 2007; Oxford 1998) ning erapoolikuse ja ükskõiksuse tajumise demotiveeriv mõju (Oxford 1998; Muhonen 2004; Kikuchi 2015). Siinses uuringus tuli ka välja, et õpetajad ei ole harjunud analüüsima enda mõju õpilaste õpimotivatsiooni kujunemisele. 
Kolmandaks selgus siinses uuringus õpperühma oluline mõju õppimissoovile. Kõige tugevamalt mõjutavad õpilasi siinkohal suhted kaaslastega. Kui need on halvad, siis kahaneb ka õppimissoov. Ka õpperühma mõne liikme passiivsus, nõrk keeleoskustase ja tunni segamine mõjub teiste õppimissoovile negatiivselt. Õpetajad ei osanud mitmeid õpperühmaga seotud demotiveerivaid tegureid märgata või ei pidanud neid oluliseks.

Kokkuvõttes selgus käesolevas uuringus rida demotiveerivaid tegureid, mis õpilasi eesti keele kui teise keele tundides mõjutada võivad. Et uuringu eesmärk oli tuua välja vaid õpisoovi kahandavad asjaolud, jäi kõik positiivne siinkohal tähelepanuta, mis ei tähenda, et positiivset tundides ei ole. Samas võivad tugeva mõjuga demotiveerivad tegurid õppimissoovi kahandada, nii et positiivne ei pääse enam mõjule. Demotivatsioon on teatud mõttes loomulik ja käib alati motivatsiooniga kaasas. Kui demotiveerivaid tegureid on aga palju või nad mõjuvad õppijale sageli, võib see põhjustada eesti keele kui teise keele õpimotivatsiooni järk-järgulise vähenemise ja lõppeda halvimal juhul isegi amotivatsiooniga ehk motivatsiooni täieliku kadumisega.

Seega on õpetajatel kindlasti vaja demotivatsiooniprotsessi paremini tunda ja teadvustada, mis võimaldaks neil teha õppetöös vajalikke muudatusi. Oleks vaja rohkem arvestada õppeteemade ja õppetegevuste huvitavuse olulisust õpimotivatsiooni kujunemisel. Õpitava liigse raskuse vähendamiseks on vaja täpsemaid teadmisi eesti keele kui teise keele loomulikust arengurajast, oskusi valida õpilaste tasemele sobivamaid õppematerjale ja -tegevusi ning anda õpilastele toetavamat tagasisidet. Õpetajad peaksid ka paremini tajuma enda meeleolu ja käitumise mõju õpilastele ning olema pädevamad õpperühma atmosfääri kujundamisel. Kõike siinkohal väljatoodut on vaja senisest rohkem õppida ja harjutada nii õpetajate põhi- kui ka täiendõppes. Ka õpilastele tuleks teadvustada demotivatsiooni olemust ja õpetada strateegiaid sellega toimetulekuks.

Et tegemist on olulise valdkonnaga, vajab see teema kindlasti ka jätkuvat uurimist. Uurida tasuks näiteks erineva õppeedukuse ja 
keeleoskustasemega õpilaste demotivatsiooni, eri vanuses õpilaste demotivatsiooni ning poiste ja tüdrukute demotivatsiooni. Huvitav ja vajalik oleks uurida võimalusi vähendada demotivatsiooni õppetegevuste või muude tegurite muutmisega. Praeguseks ongi juba valminud Jelena Berezina magistritöö (2020), milles näidatakse julgustavaid tulemusi: mängustatud õppeprogrammi mõjul muutus vähemotiveeritud ja passiivne kolmanda klassi õpperühm tunduvalt motiveeritumaks ja aktiivsemaks.

\section{Tänusõnad}

Artikli valmimist on toetanud teadus- ja arendusprojekt LLTOM18066 "Rändesõltuvus ja lõimumise väljakutsed Eesti riigile, tööandjatele, kogukondadele ja haridusele".

\section{Kirjandus}

Berezina, Jelena 2020. Mängustatud õppe mõjust õpilaste eesti keele kui teise keele kasutamisele 3. klassi näitel ['The Effect of Gamified Learning on the Use of Estonian as a Second Language by Third Grade Pupils']. Magistritöö. Tallinn: Tallinna Ülikool.

Bekleyen, Nilüfer 2011. Demotivating factors in the EFL environment. - Frontiers of Language and Teaching 2, 151-156.

Brophy, Jere 2016. Kuidas õpilasi motiveerida. Käsiraamat õpetajatele ['Motivating Students To Learn']. Tallinn: Archimedes.

Dörnyei, Zoltán 1998. Motivation in second and foreign language learning. - Language Teaching 31 (3), 117-135. https://doi.org/10.1017/ S026144480001315X

Dörnyei, Zoltán 2001a. Motivational Strategies in the Language Classroom. Cambridge: Cambridge University Press. https://doi.org/10.1017/ CBO9780511667343

Dörnyei, Zoltán 2001b. Teaching and Researching Motivation. Harlow: Longman \& Pearson Education.

Dörnyei, Zoltán, Ema Ushioda 2011. Teaching and Researching Motivation. Applied Linguistics in Action Series. Harlow: Pearson.

Dörnyei, Zoltán, Kata Csizér 1998. Ten commandments for motivating language learners: Results of an empirical study. - Language Teaching 2, 203-229. 
EIS = Eksamite infosüsteem ['Examination Information System']. https://eis.ekk. edu.ee/eis/eksamistatistika (3.9.2020).

Ellis, Rod 1994. The Study of Second Language Acquisition. Oxford: Oxford University Press.

Gardner, Robert C. 1985. Social Psychology and Second Language Learning: The Role of Attitudes and Motivation. London: Edward Arnold.

Gardner, Robert C. 2007. Motivation and second language acquisition. - Porta Linguarum 8, 9-20.

Hamada, Yo 2008. Demotivators for Japanese Teenagers. - Journal of the PanPacific Association of Applied Linguistics 12 (2), 1-23.

Hamada, Yo, Kazuya Kito 2008. Demotivation in Japanese high schools. - JALT 2007 Conference Proceeding. Tokyo: JALT, 168-178.

Kikuchi, Keita 2015. Demotivation in Second Language Acquisition. Insights from Japan. Bristol \& Buffalo \& Toronto: Multilingual Matters. https://doi. org/10.21832/9781783093953

Kikuchi, Keita, Hideki Sakai 2009. Japanese learners' demotivation to study English: A survey study. - JALT Journal 31 (2), 183.

Metslang, Helena, Triin Kibar, Mare Kitsnik, Jevgenia Koržel, Ingrid Krall, Anastassia Zabrodskaja 2013. Kakskeelne õpe vene õppekeelega koolis. Uuringu lõpparuanne ['Bilingual Learning in Russian-Medium Schools. Final Research Report']. Tallinn: Tallinna Ülikooli Kirjastus. http://hdl. handle.net/10062/40937

Muhonen, Jenni 2004. Second Language Demotivation: Factors that Discourage Pupils from Learning the English Language. A Pro Gradu Thesis. Jyväskylä: University of Jyväskylä. http://urn.fi/URN:NBN:fi:jyu-2004944808

Oxford, Rebecca, L. 1998. The unravelling tapestry: Teacher and course characteristics associated with demotivation in the language classroom. - Paper presented at the TESOL98 Congress, Seattle, USA.

Ryan, Richard M. 2012. The Oxford Handbook of Human Motivation. Oxford Library of Psychology. Oxford: Oxford University Press. https://doi. org/10.1093/oxfordhb/9780195399820.001.0001

Ryan, Richard M., Edward L. Deci 2000. Self-determination theory and the facilitation of intrinsic motivation, social development, and well-being. - American Psychologist 55 (1), 68-78. https://doi.org/10.1037/0003-066X.55.1.68

Selliov, Rena 2016. Eesti keelest erineva emakeelega põhikooli lõpetajate eesti keele oskus ['Estonian Language Proficiency of Basic School Graduates with a Mother Tongue other than Estonian']. Tartu: Haridus- 
ja Teadusministeerium. https://www.hm.ee/sites/default/files/hmin_b1_ keele_tase.pdf (3.9.2020).

Sooalu, Monika 2016. Õpilaste demotivatsiooni põhjused 9. klassi eesti keele teise keelena tundides ['Reasons of Students' Demotivation in the 9th Grade Estonian as a Second Language Lessons']. Magistritöö. Tallinn: Tallinna Ülikool.

Zhang, Qin 2007. Teacher misbehaviors as learning demotivators in college classrooms: A cross-cultural investigation in China, Germany, Japan, and the United States. - Communication Education 56 (2), 209-227. https://doi. org/10.1080/03634520601110104 


\title{
Why does the desire to learn Estonian sometimes disappear? Reasons of students' demotivation in the 9th grade lessons
}

\author{
MARE KITSNIK ${ }^{1}$, MONIKA SOOALU \\ University of Tartu'
}

Motivation is considered the main factor of productivity in language study. The motivation of learning the second language is influenced on cultural context (the value of language learning, the faith in success etc) and on educational context (curriculum, teacher, learning activities, teaching materials, learning group). The both motivation factors affect the second language learner at the same time (these encourage the learners to study) but the demotivation factors (that push the learners away from learning) as well.

The teachers who teach Estonian as the second language regard the low learning motivation the main problem connected with the language study. At the same time they cannot see their own role in rising learners motivation and prevent demotivation. The main aim of this research is to identify the main factors of demotivation in learning Estonian as the second language and study how the same factors have been perceived by the teachers of Estonian as the second language.

To get answers to the questions of this research 20 semi-structured interviews were held among the 9-class students learning Estonian as the second language and four teachers of Estonian as the second language. The results were encoded and classified by demotivation factors.

Analysing the students' answers there appeared 16 demotivation factors, that were grouped into three larger groups: the factors connected with learning activities, factors connected with a teacher, and factors connected with a learning group.

The demotivation factors connected with teachers in the students' opinion are: teachers' unfriendliness, teachers' unfair attitude, not understanding of teacher's explanations, fear, forcing, lack of teacher's attention and teachers' unsuitable teaching style. 
Then follows the demotivation connected with learning activities, where five main factors appeared: uninteresting topics, dullness of learning activities, difficulty of the learning, unnecessity of the learning subject and too capacious learning materials.

There appeared four main factors that were connected with the group of learners: bad relationship between students, learners' inactivity, disturbance in classes and the uneven level of students.

In this paper there appeared that the teachers are not used to analyse the factors that demotivates their students in classroom activities and learning topics. The results of the current paper can be used in completing training programmes for the teachers of Estonian as the second language and carrying out the training. If teachers understand what demotivates their students, they have better chance to understand their own role in decreasing of demotivation factors.

Keywords: learning motivation; demotivation; teacher; learning activities; study group; Estonian as a second language

\section{Mare Kitsnik}

Tartu Ülikooli eesti ja üldkeeleteaduse instituut

Jakobi 2, 51005 Tartu, Estonia

marekitsnik@gmail.com

\section{Monika Sooalu}

Lasnamäe gümnaasium

Pae 59, 13621 Tallinn, Estonia

monikasooalu196@gmail.com 